\begin{tabular}{|l|l|l||}
\hline \multicolumn{2}{|c|}{ PublisherInfo } \\
\hline \hline PublisherName & $:$ & BioMed Central \\
\hline \hline PublisherLocation & $:$ & London \\
\hline \hline PublisherImprintName & $:$ & BioMed Central \\
\hline \hline
\end{tabular}

\title{
Endotracheal tube and VAP
}

\begin{tabular}{|l|l|l||}
\hline \multicolumn{2}{|c||}{ ArticleInfo } \\
\hline \hline ArticleID & $:$ & 4169 \\
\hline \hline ArticleDOI & $:$ & $10.1186 /$ ccf-1999-2301 \\
\hline \hline ArticleCitationID & $:$ & 2301 \\
\hline \hline ArticleSequenceNumber & $:$ & 28 \\
\hline \hline ArticleCategory & $:$ & Paper Report \\
\hline \hline ArticleFirstPage & $:$ & 1 \\
\hline \hline ArticleLastPage & $:$ & 3 \\
\hline \hline & $:$ & RegistrationDate : 1999-11-23 \\
ArticleHistory & $:$ & OnlineDate \\
\hline \hline ArticleCopyright & $:$ & Current Science Ltd1999-11-23 \\
\hline \hline ArticleGrants & $:$ & \\
\hline \hline ArticleContext & $:$ & 1305422 \\
\hline \hline
\end{tabular}




\section{Keywords}

Antibiotic resistance, microbial biofilm, ventilator-associated pneumonia

\section{Comments}

This interesting study helps to explain the mechanism behind the association of endotracheal intubation with VAP. The value of routine antibiotic sensitivity testing to biofilm microorganisms is also questioned. In clinical terms, this paper supplies more ammunition for early extubation and the use of noninvasive modes of ventilation (if support is still required) in an attempt to reduce VAP.

\section{Introduction}

The endotracheal tube (ET) is a risk factor for ventilator-associated pneumonia (VAP) because host defences are circumvented. Work has shown that microorganisms may cling to the ET and secrete an exopolysaccharide (the biofilm) that encases bacteria, making them relatively resistant to antibiotics. Suctioning, or even the ventilator gas flow, may then uproot segments of biofilm and carry potentially resistant organisms into the lungs.

\section{Aims}

To identify whether ET biofilm is associated with VAP (as defined in paper).

\section{Methods}

In total, 20 patients with VAP and 20 patients without VAP were studied in two intensive care units (ICUs). Patients with infections appearing within $48 \mathrm{~h}$ of intubation were excluded, since these were considered nosocomial in origin. During ventilation, tracheal secretions were sent for bacteriological culture and following extubation, the ET biofilm microbiology was examined. Microorganism 
genotyping and antibiotic susceptibility testing was undertaken when the same organism was isolated from both ET and tracheal secretions.

\section{Results}

Biofilm was identified in all ETs in the study. Highly pathogenic organisms were found in all VAP patient ETs, but in only $30 \%$ of control ETs. Pathogenic microorganisms were identified in $85 \%$ of tracheal secretions in the VAP group, compared to $20 \%$ in the control. However, no matching pairs of organisms were found in the control group, compared to $70 \%$ in the VAP group (following genotyping). Organisms identified for matching pairs were Pseudomonas sp, Staphylococcus aureus, Enterococcus faecalis, Candida sp and EGNB (Proteus, Klebsiella and Enterobacter). Minimal inhibitory concentrations for commonly administered antibiotics showed no significant differences between tracheal and ET organisms in planktonic growth mode, but minimal bactericidal concentrations were significantly lower in tracheal isolates when compared to ET isolates in biofilm growth mode.

\section{Discussion}

ET biofilm is implicated in the pathogenesis of VAP, and was present in all patients being ventilated in the ICU. Previous work has shown that this biofilm develops within hours of intubation and so it is probable that colonisation of the ET precedes that of the airways. Microorganisms within the biofilm are metabolically inactive, so the usual antibiotic sensitivity testing based on minimal inhibitory concentration (with the isolated organism in suspension in vivo) is inappropriate. Methods to determine sensitivities against these organisms in biofilm growth mode need to be developed.

\section{References}

1. Adair CG, Gorman SP, Feron BM, Byers LM, Jones DS, Goldsmith CE, Moore JE, Kerr JR, Curran MD, Hogg G, Webb CH, McCarthy GJ, Milligan KR: Implications of endotracheal tube biofilm for ventilator-associated pneumonia. Intensive Care Med. 1999, 25: 1072-1076.

This PDF file was created after publication. 